\title{
Evcil bir güvercinde generazlize tüberküloz olgusu
}

\author{
Adem Milletsever ${ }^{1}$, Özlem Özmen ${ }^{1}$
}

${ }^{1}$ Department of Pathology, Faculty of Veterinary Medicine, Burdur Mehmet Akif Esoy University, Burdur/TURKEY

Anahtar Kelimeler:

güvercin

tüberkülozis

nekropsi

histopatoloji

Ziehl-Neelsen metodu

Key Words:

pigeon

tuberculosis

necropsy

histopathology

Ziehl-Neelsen method

$\begin{array}{ll}\text { Received } & : 03.05 .2021 \\ \text { Accepted } & : 08.07 .2021 \\ \text { Published Online }: 31.08 .2021 \\ \text { Article Code } & : 930980\end{array}$

Sorumlu Yazar:

A MILLETSEVER

(adem.milletsever@gmail.com)

ORCID

A MILLETSEVER: 0000-0002-3614-7798

Ö ÖZMEN : 0000-0002-1835-1082

\begin{abstract}
ÖZ
Bu olguda Burdur Mehmet Akif Ersoy Üniversitesi Veteriner Fakültesi Patoloji Anabilim Dalına nekropsi için getirilen 3-4 yaşlı, dişi, evcil bir güvercinde saptanan generalize tüberküloz olgusu tanımlandı. Hayvan sahibinden alınan anamnezde 3-4 ay önceden başlayan halsizlik, iştahsızlık, durgunluk, tüylerde kabarma ve zayıflık bulguları belirtildi. Nekropside hayvanın aşırı kaşektik olduğu, tüylerin kabarık ve karıșık, anüs çevresindeki tüylerin ise dışkı ile bulașık olduğu gözlendi. İç bakıda akciğer, karaciğer, perikart ve bağırsak serozalarında yoğun olmak üzere tüm iç organlarda büyüklükleri $0,5-1,5 \mathrm{~cm}$ arasında değişen bazıları birbirleri ile birleşmiş şekilde çok sayıda sarımsı-gri renkli nodüler yapılar saptandı. Lezyonlu doku örnekleri rutin takip ișleminden geçirilerek histopatolojik olarak incelendi. Mikroskobik incelemede odakların merkezlerinde belirgin kazeifikasyon nekrozu, çevrelerinde çok sayıda mononüklear yang1 ve dev hücrelerinin bulunduğu dikkati çekti ve etrafları bağ doku ile çevrili tipik granülomlar saptandı. Ziehl-Neelsen metoduna göre boyanan kesitlerde kırmızı basiller şeklinde çok sayıda mikobakteriyel etken görüldü. Makroskobik ve mikroskobik bulgular ışığında olguya tüberküloz teşhisi konuldu.
\end{abstract}

\section{A case of generalized tuberculosis in a domestic pigeon}

\begin{abstract}
In this study, a case of generalized tuberculosis diagnosed in a 3-4 aged, female, domestic pigeon brought to Burdur Mehmet Akif Ersoy University, Faculty of Veterinary Medicine, Department of Pathology for necropsy was described. At the anamnesis, weakness, anorexia, puffy and ruffled feathers that started 3-4 months ago were stated. At necropsy, the animal was excessively cachectic, the feathers were fluffy, irregular and the feathers around the anus was contaminated with feces. Gross examination revealed numerous yellowish-grey colored nodules, some of which were combined with each other, ranging in size from 0,5 to $1,5 \mathrm{~cm}$ localized all internal organs serosal surface such as lung, liver, pericardium and intestines. Tissue samples taken from the lesions were examined histopathologically after routine tissue processing. Microscopical examination revealed that typical tubercles with prominent caseification necrosis in the centers of the foci, numerous mononuclear inflammatory giant cells around them and surrounded by connective tissue. A large number of mycobacterial agents were observed as red stained bacilli on sections stained with the Ziehl-Neelsen method. Diagnosis of tuberculosis was made in the light of gross and histopathological findings.
\end{abstract}

\section{GİRİ̧}

Mycobacterium avium çeşitli kuş türlerinde çeşitli organlarda granülomatöz oluşumlar ile karakterize kronik enfeksiyona neden olan bulaşıcı bir kanatlı hastalık etkenidir $(1,2)$. Bununla birlikte kanatlı tüberkülozu genellikle kuşların Mycobacterium avium subsp. avium, Mycobacterium avium subsp. silvaticum ve $M y$ cobacterium genavense etkenleri ile oluşur. $(3,4)$. Özellikle güvercinlerin $M$. avium enfeksiyonuna karşı yüksek direnç gösterdiği bulunmuştur (5). Mycobacterium avium, pek çok yabani ve serbest uçan kuş türünde tespit edilmiştir ve sülünler özellikle duyarlıdır. Domuz, tavşan ve vizon gibi memeli türleri arasında M. avium enfeksiyonu progresif hastalığa neden olabilir ayrıca insanlarda tüberkülozdan da sorumlu olduğu için insan sağlı̆̆1 açisından önem arz etmektedir (6).

Bu çalışmanın amacı bir güvercinde rastlanan generalize tüberküloz olgusunun patolojik bulgularının sunulmasıdır.

\section{OLGU}

Bu çalışmanın materyalini Burdur Mehmet Akif Ersoy Üniversitesi Veteriner Fakültesi Patoloji Anabilim Dalına canlı olarak getirilen 3-4 yaşlı evcil bir güvercin (Columba livia f. Domestica) oluşturdu. Güvercinde 3-4 aydır devam eden halsizlik, iştahsızlık, durgunluk, tüylerde kabarma ve zayıflık bulguları bulunduğu ifade edildi. Durumu kötü olan güvercin 2 gün sonra öldü ve nekropsisi yapıldı. Nekropside tüm iç organlarda granülomatöz lezyonlar tespit edildi. Lezyonlu alanlardan alınan organ numuneleri histopatolojik inceleme için \%10 tamponlu formaldehit içerisinde tespit edildi. İki günlük fikzasyonun ardindan dokular rutin doku takibinden geçirilerek parafine gömüldü. Bloklardan mikrotom (Leica Microsystems, Wezlar, Almanya) ile $5 \mu \mathrm{m}$ kalınlığında kesitler alınarak, hematoksilen-eozin (HE) ve Ziehl-Neelsen metodu ile boyand1 ve mikroskobik olarak incelendi.

Güvercinin canlı olarak ilk getirildiğinde klinik incelemesinde halsizlik, iştahsızlık, durgunluk, tüylerde kabarma, zayıflık 
ve gögüs kaslarının atrofisi dikkati çekti. Yapılan nekropside ise karaciğerin büyümüș olduğu (Şekil 1A), akciğerde, epikartta (Şekil 1B), bağırsak serozaları ile midede (Şekil 1C-D) ve karaciğerde yoğun olmak üzere tüm iç organlarda büyüklükleri 0,5-1,5 cm arasında değişen bazıları birbirleri ile birleşmiş şekilde çok sayıda sarımtırak renkli ve sert nodüler yapılar saptand1 (Şekil 1A-D). Nodüllerin kesit yüzlerinde sarımtırak renkli kazeifiye nekrotik kitleler gözlendi. Histopatolojik inceleme-

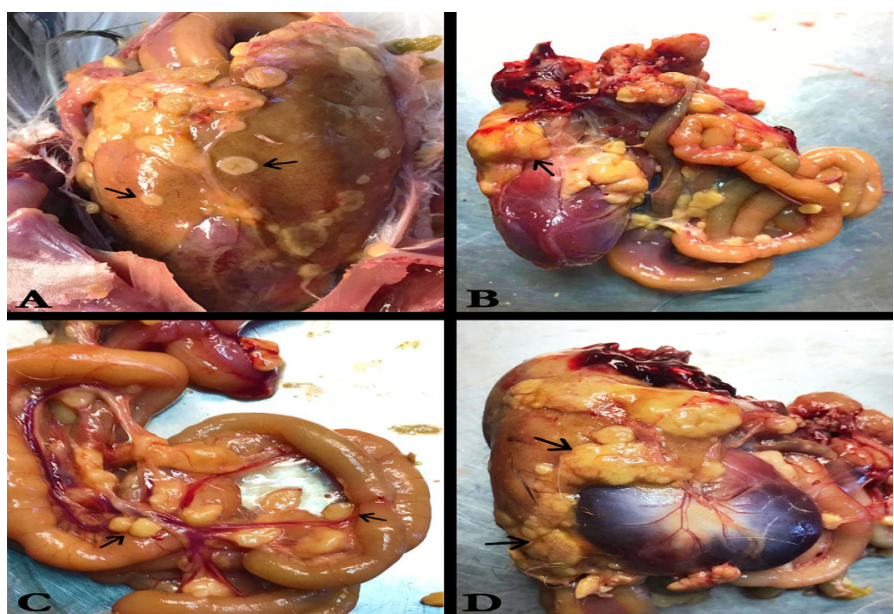

Şekil 1. A: Karaciğerde büyüme ve yoğun şekilde büyüklükleri 0,5$1,5 \mathrm{~cm}$ arasında değişen sarımtırak renkli nodüler yapılar (oklar); B: Epikartta kazeifiye nodüler yapılar (ok); C: Bağırsak serozasında nodüler yapılar (oklar); D: Midede sarımtırak renkli nodüler yapılar (oklar)

de granülomların merkezinde belirgin kazeifikasyon nekrozu, çevrelerinde çok çekirdekli dev hücrelerinin bulunduğu ve etrafları bağ doku ile çevrili tipik tüberküller saptandı. Kaslı mide serozasinda, periton üzerinde peritoneal tüberküloz lezyonları görüldü. Ovaryum (Şekil 2A), dalak, böbrek, mide bağırsak sisteminin tamamında tüberküllere rastlandı. Kalp ve akciğerlerde ise kazeifikasyon nekrozu ile epiteloid ve dev hücreleriyle karakterize tüberküller (Şekil 2B) görüldü. Karaciğerde çok sayıda konglomere tüberküllere rastlandı (Resim 2C). Ayrıca kemik iliğinde de kazeifikasyon nekrozları ile karakterize tipik tüberküller gözlendi (Şekil 2D).

Ziehl-Neelsen boyama methodu ile boyanan doku kesitlerinde, çok çekirdekli dev hücrelerde çok sayıda aside dirençli kırmızı renkli basil şeklinde mikobakteriyel etkenlere rastlandı (Şekil 3).

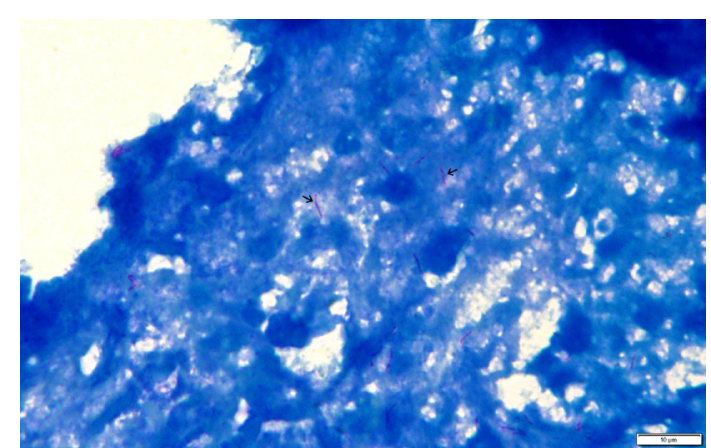

Şekil 3. Aside dirençli tüberküloz basilleri (oklar), Ziehl Neelsen metodu, bar:10 $\mu \mathrm{m}$

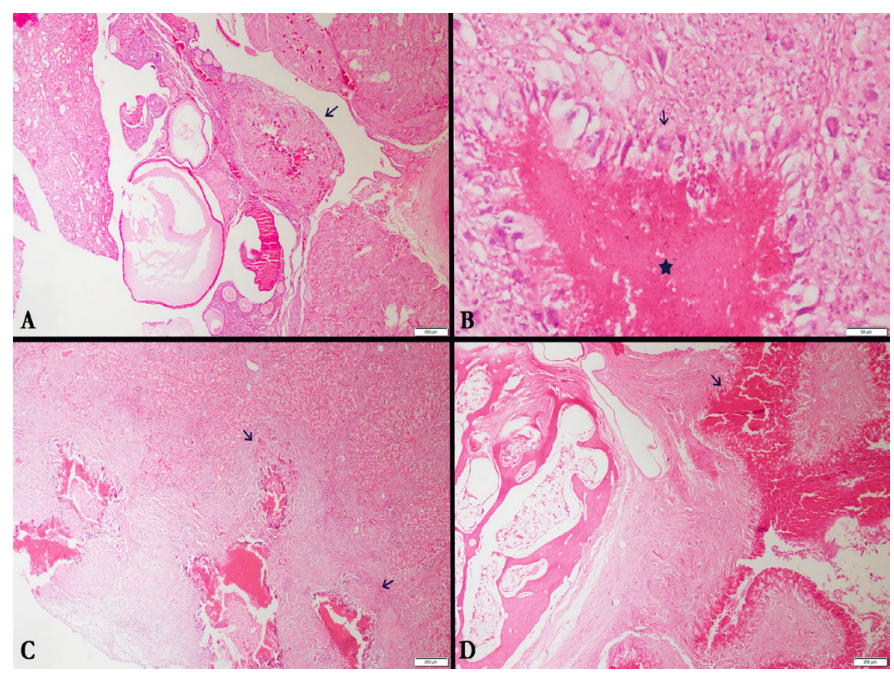

Şekil 2. A: Ovaryumda granülom (ok), (H\&E), Bar:200 $\mu \mathrm{m}, \mathrm{B}$ : Bir tüberkülün yakından görünümü, dev hücresi (ok) ve nekroz

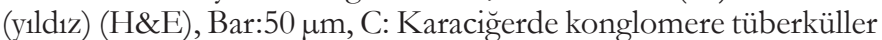
(oklar), (H\&E), Bar:200 $\mu \mathrm{m}, \mathrm{D}$ : Kemik iliğinde granülom (ok), (H\&E), Bar:200 $\mu \mathrm{m}$

\section{TARTIŞMA}

Kanatlı tüberkülozu dünya genelinde endemik olarak, yabani ve evcil kanatlı türlerinde mortalite ve morbiditesi yüksek, salginlar halinde seyreden bir hastalıktır. Bu hastalık, insan sağlığını tehdit edebilen zoonotik potansiyeli yanı sıra çeșitli hayvan türlerinde de hastalık olușturabilen bulașıcı bir hastalıktır (7). M. avium kanatlı tüberkülozunun en önemli etkenidir ve yaşı hayvanlarda daha yaygındır. Çünkü daha uzun süre etkene maruz kalma, hastalı̆ın şekillenmesi için büyük bir firsat yaratır. Bu sebeple genellikle iki yaşın üzerindeki güvercinlerde görülür (7-9). Özellikle tavuklarda yumurta kalitesi ve karkas ağırlıklarına olumsuz etkileri nedeniyle ekonomik olarak önemli bir yere sahiptir. Modern yetiştiricilikte bu hastalık eradike edilmiş olmasına rağmen yabani kanatlı türlerinden kaynaklanabilecek enfeksiyon riski hala devam etmektedir.

Lezyonların ilk şekillendiği yer, maruziyet yolunun bir göstergesidir. Bağırsak lezyonları, kontamine yem veya su ile etkenin alındığını düşündürür. Kuşlarda, enfeksiyonun doğal yolunun, memeliler için yaygin olarak tarif edilen solunum yolundan farklı olarak, oral yoldan olduğu düşünülmektedir. Bu nedenle, kanatlı tüberkülozu önce gastrointestinal sistemi ve karaciğeri etkiler ve daha sonra diğer organlara yayılır (10).

Patolojik değișiklikler, genellikle dalak, karaciğer ve bağırsak serozasında lokalize olan granülomlarla karakterizedir. Bu tip lezyonların organ dağılımı, bakterilerin bağırsak mukozasına ilk yerleşimi ve ardından hematojen olarak yaylımını göstermektedir. Kloakal kontaminasyonun olabileceği gösterilmiştir. Ayrıca deri yoluyla da enfeksiyon bildirilmiştir. Lezyonlar gri-sarımtırak renkte, nodüler yapılar șeklinde olup genellikle karaciğer, dalak, bağırsak, kemik iliğinde, akciğerde ve kalpte daha az olarak diğer organlarda rastlanır $(10,11)$.

Tüberküloz nedenli artritis durumlarında topallık nedeniyle sallantılı bir atlama yürüyüşü gözlenebilir, bacak kemiklerinin veya eklemlerin kemik iliğinde tüberküloz lezyonları şekillenebilir. Bazı kuşlar oturur pozisyonda gözlenebilir. Felç tab- 
losuyla karşılaşılabilir. Ölümle sonuçlanan olgularda büyümüş karaciğer veya dalağın ruptura uğramasıyla ortaya çıkan büyük kanamalar şekillenebilir. Bu durumda, bazen kuşlar bedensel olarak iyi kondisyonda iken aniden ölebilir ve nekropside ileri düzeyde tüberküloz lezyonları gösterebilirler $(9,10)$.

Bu olguda akciğer, karaciğer, epikart ve bağırsak serozalarında yoğun olmak üzere tüm iç organlarda büyüklükleri 0,5 $1,5 \mathrm{~cm}$ arasında değişen bazıları birbirleri ile birleşmiş şekilde çok sayıda sarımtırak renkli nodüler yapılar saptanmıştır. Kemik iliği yayılımı birçok kemikte saptanmıştır. Organlarda herhangi bir ruptur ve kanama görülmemiştir.

Kanatlı tüberküloz hastalığında histopatolojik incelemelerde merkezi kazeifikasyon nekrozu, yabanci cisim dev hücreleri, epiteloid histiyositler, lökosit ve lenfositler gözlenmekle birlikte diğer canlılarda gözlenen tüberkülozda oluşan kireçlenmeye pek rastlanmaz. Ziehl-Neelsen metodu ile boyanmalarda kirmızı basiller görülür $(4,6,7)$.

Olgumuzda ise lezyon odaklarının merkezlerinde belirgin kazeifikasyon nekrozu, çevrelerinde çok çekirdekli dev hücrelerinin bulunduğu ve etraflarının bağ doku ile çevrili olduğu tipik tüberküller birçok organda saptanmıştır. Kaslı mide altında periton üzerinde peritoneal tüberküloz lezyonları görülmüş olup kemik iliğinde de kazeifikasyon nekrozlu çok sayıda granülomatöz lezyonlar ile bağırsağın serozasında tüberküller, epiteloid ve dev hücrelerine rastlanmıştır. Ziehl-Neelsen boyama metodu ile boyanan doku kesitlerinde, çok çekirdekli dev hücrelerinde çok sayıda aside dirençli kırmızı renkli basiller dikkati çekmiştir.

Ülkemizde güvercin yetiştiriciliği hobi ve ekonomik gelir amaçlı yapılmaktadır. Güvercinlerde tüberkülozis sık rastlanılmamakta ya da göz ardı edilmektedir. Bu olguda kanatlı tüberkülozis hastalığının gerek ekonomik anlamda hayvan yetiştiriciliğine olumsuz etkileyeceği ve insan sağlığına tehlike oluşturacağına vurgu yapılmıştır.

\section{SONUÇ}

$\mathrm{Bu}$ olgu sunumunun bulguları tüberküloz hastalığının güvercinlerde klinik bulgu göstermeden uzun süre kalabileceğini ve özellikle sürü halindeki hayvanlarda bulaşmaya sebep olabileceğini göstermiştir. Ayrıca hastalı̆̆ın tüm organlarda yerleşebileceği bu sebeple kronik kaşeksisi olan güvercinlerde göz önünde tutulması gerektiğini düşündürmektedir.

\section{BEYANNAMELER}

\section{Etik Onay1}

Uygulanamaz

\section{Çıkar Çatışması}

Yazarlar, herhangi bir çıkar çatışması beyan etmemektedir.

\section{Yazar Katkıları}

Fikir, Kavram ve Tasarım: A. Milletsever, Ö. Özmen

Veri Toplama ve Analiz: A. Milletsever, Ö. Özmen

Makalenin Yazımı: A. Milletsever

Eleştirel İnceleme: Ö. Özmen

\section{Veri kullanılabilirliği}

$\mathrm{Bu}$ çalışmanın bulgularını destekleyen veriler makul talep üzerine sorumlu yazardan temin edilebilir.

\section{KAYNAKLAR}

1. Kutsal O, Saglam M. Tuberculosis in pigeons (in Turkish). Ankara Univ Vet Fak Derg. 1988; 35:545-552.

2. Sezen İ, Erer H, Erganiş O. Bir güvercinde tüberküloz olgusu. Eurasian J Vet Sci. 1986;2(1):163-166.

3. Dvorska L, Bull J, Bartos M, Matlova L, Svastova P, Weston T, Kintr J, Parmova I, Van Soolingen D ve Pavlik I. A standardized restriction fragment length polymorphism (RFLP) method for typing Mycobacterium avium isolates links IS901 with virulence for birds. J. Microbiol. Methods. 2003;55(1):1127.

4. Pavlik I, Svastova P, Bartl J, Dvorska L ve Rychlik I. Relationship between IS901 in theMycobacterium avium complex strains isolated from birds, animals, humans and environment and virulence for poultry. Clin Diagn Lab Immunol. 2000;7(2):212-217.

5. Hejlicek K, ve F Treml. Epizootiology and pathogenesis of avian mycobacteriosis in domestic pigeons (Columba livia $\mathrm{f}$. domestica). Vet Med (Praha). 1994;39(10):615-24.

6. Bougiouklis P, Brellou G, Fragkiadaki E, Lordanidis P, Vlemmas I, ve Georgopoulou I. Outbreak of avian mycobacteriosis in a flock of two-year-old domestic pigeons (columba livia f. domestica). Avian Diseases. 2005;49(3):442-445.

7. Glunder G. Infection of pigeons as a risk to the health of humans and animals. Dtsch. Tierarztl. Wochenschr. 1989;96(3):112-116.

8. Gonzalez M, Rodriguez-Bertos A, Gimeno I, Flores J ve Pizarro M. Outbreak of avian tuberculosis in 48-week-old commercial layer hen flock. Avian Diseases. 2002;46(4):10551061.

9. Van Der Heyden N. Clinical manifestations of mycobacteriosis in pet birds. Semin. Exotic Pet Med. 1997;6(1):18-24.

10. Dhama K, Mahendran M, Tiwari R, Dayal S, Kumar $\mathrm{D}$, Singh $\mathrm{S}$ ve Sawant M. Tuberculosis in birds: insights into the Mycobacterium avium infections. Vet Med Int. 2011; Vol. 2011:1-14

11. Sanford S, Rehmtulla A, Josephson G. Tuberculosis in farmed rheas (Rhea americana). Avian Diseases. 1994;38(1):193-196. 